\title{
What Can an Understanding of the Changing Small-Scale Forest Owner Contribute to Rural Studies? The Swedish
}

\section{Case}

\author{
E. Carina H. Keskitalo ${ }^{1,2}$
}

Accepted: 3 October 2019 / Published online: 25 October 2019

(c) The Author(s) 2019

\begin{abstract}
Over the centuries, Swedish rural areas have been formed in close interaction with their inhabitants and different and various uses. Based on studies, particularly of "new forest owners" in Sweden, this article illustrates how an understanding of forest and forest ownership can highlight the dynamic and shifting role of rural areas: as both rural and urban, based on both forest property and second-home ownership. It also illustrates that rural areas are not only post-productive but also continuously over time production areas, in addition to many other use patterns, and that rural areas can be areas of forest-related industrial and services growth, and thus rural growth. The article also illustrates that forest areas in Sweden, but also more broadly Fennoscandia, can be seen as areas with different habitation patterns and linkages between nature and population than what has often been described in broader rural literature.
\end{abstract}

Keywords Small-scale forest owners $\cdot$ Change $\cdot$ Characteristics $\cdot$ Sweden $\cdot$ Rural

\section{Introduction and Aim}

Conceptions of the rural in rural studies literature have often focused on agricultural uses of land (Shubin 2006). In some cases, rural studies can even be seen to have fallen into the dichotomy resultant of a frontier conception of land (Keskitalo manuscript), in which land is firstly separated from an integrated relation to the human and viewed as external to areas of habitation. A legacy of this type of conception has been that rural areas have been-and may still be even todayconceived of either as a rural idyll or, in juxtaposition, as a place of backwards

E. Carina H. Keskitalo

carina.keskitalo@umu.se

1 Swedish University of Agricultural Sciences (SLU), Umeå, Sweden

2 Umeå University, Umeå, Sweden 
development (e.g. Swaffield and Fairweather 1998). These conceptions of rural or nature areas are often seen as related to an understanding of them as either hostile or idyllic "wilderness", with mythical and often even religious attributes (Nash 2014), and subsequently destined to either be "conquered" by man and transformed into "civilisation" or be entirely left alone and preserved in their "original" state (e.g. Cronon 1996; cf. Keskitalo manuscript).

While such conceptions of nature as "wilderness" have long been recognised as constructed (e.g. Nash 2014; Cronon 1996), these descriptive traditions have nevertheless proven hard to shake. Even today, they can be seen as embedded in problems related to rural planning (which often regards vastly varying areas with a similar conception of "rural"), and in conceptions which highlight areas as intended either for use (productivism) or for urban and touristic leisure (postproductivism) (cf. Morrison et al. 2015; Scott 2008; Hidle et al. 2006).

Many of these type conceptions also do not clearly recognise the potential multiple and varied uses of land that do not necessarily fall under an either-or label. These problems are illustrated in conceptions that highlight agriculturewhich was the historic frontier focus for acculturating land and thereby removing it from "wilderness" (e.g. Murdoch and Pratt 1993) —rather than other uses, such as those related to forest. To a large extent, rural studies have thereby been constructed through conflicts with conceptions of the rural that both mis-describe large and influential forest practices, and dichotomise rural life (e.g. Cruickshank 2009).

Contrary to these types of assumptions, northern Sweden, as well as northern Finland and Norway, has been inhabited over a historically long time, resulting in the landscape being formed by multiple uses at and beyond places of residence. Land areas were regularly used for multiple purposes, including not only agriculture at the homestead but also an integrated and important role of for instance hunting, fishing and berry/mushroom picking in outlying areas (so-called utmark or erämaa). Forest and forestry were thus used for multiple purposes, whereby the timber value was only one of several values (for firewood, housing, and also tar production in early industrial usage) (e.g. Svensson 2016; Johansson 2002). Different groups focused to different degrees on practices such as coastal fishing or reindeer herding. Thus, for a long period of time, agriculture was not any single dominating land use, and it can be seen that there was not necessarily a clear distinction between "natural" and other areas (Keskitalo manuscript). Thus, rather than what is today often an assumption in international literature, the northern European understanding of land can be seen as more integrated: it was based on numerous practices, included numerous groups, and developed over time (Nash 2014; cf. Keskitalo manuscript).

It is assumed here that this type of historical basis continues to constitute the foundation for understanding land use in northern Europe: it is not an expression of any single type of use-although there are certainly economically dominant usesrather, it is a legacy of multiple land uses and traces in the landscape. These multiple uses and interests in the landscape can be seen to manifest even today, with smallscale forest as well as second-home owners sometimes in fact living and working in multiple places, integrating multiple-use forest practices and rural part-time residence even in highly urbanised main livelihoods. 
On this basis, it becomes highly relevant to review the changes that may result from relatively place-based identities such as small-scale forest owners (who own about half of all forest in Sweden) now becoming increasingly based in urban areas-not only a generation or so away from living on the farm but perhaps several generations, and with increasingly unclear consequences for the future. Not only is forestry relevant to review as an established land use and one that has been historically highlighted in these areas, compared to the approach in rural studies, but forest and forest ownership are also relevant to review in relation to understanding how established patterns in a more integrated understanding of land may change. Does this result in shifts in what identity, relationships, attributes or use preferences the forest owner displays (a "new" compared to a "traditional" forest-owner type)? Relatedly, may such shifts even come to influence or diminish the more integrated northern European relation to nature in the case of forest owners?

This paper bases its discussion on Swedish studies, particularly work in the large research programme Planning for rural-urban dynamics: living and acting at several places (PLURAL), which was undertaken in 2011-2016 and focused on new forest owners and the change in forest ownership as a phenomenon. The programme compared areas in northern and southern Sweden and also established comparisons in relation to international literature and European cases, the latter in the concurrent EU Cost-Action FACESMAP programme (cf. Keskitalo 2017, ed). The study also draws upon additional literature that can be used to elucidate the case.

The focus on the Swedish case can be seen to provide a window not only to discussing the specific nature of northern European cases but also to understanding what this type of more integrated relationship to nature-particularly one focused on forestry-can contribute to rural studies. It aims to provide a perspective on how forests are conceived, what this type of understanding can add to the understandings of rurality, and how it differs from assumptions regarding forests as related to assumptions regarding "wilderness".

\section{Understanding Forest-Owner Ruralities in Change: Theoretical Framework and Study Design}

A focus on forest use, and understanding it as part of a more integrated framework of use that does not fall only into specific dichotomies, could be seen as a way to highlight the realities of "rural" areas, rather than merely their often assumed characteristics (Cruickshank 2009). While forests and forestry have received a relatively limited focus in rural studies literature, forests are in fact significant in relation to understanding rural issues: in the EU case, forests cover more than a third of the land area. In relation to a focus on small-scale or non-industrial private forest owners, it is significant that some $40 \%$ of this land area is owned by this type of owner (Howley 2013; Toivonen et al. 2005; Lähdesmäki and Matilainen 2014). Forest, thereby, constitutes a significant contribution in light of both rural area and population or livelihood issues.

To capture this often overlooked role of forest and forest owners, key issues to highlight real, rather than imagined, characteristics of the rural include basing 
assessments on a descriptive, statistically based understanding of features of change. While much recent work has focused on the types of "new forest owner" (often seen as typified by such non-traditional characteristics as being urban, female, or lacking a background in forestry), studies have shown that there is great variation across European countries. Thus, the variation in basis in comparison with which the "newness" is described is substantial (e.g. Hogl et al. 2005; Hujala et al. 2013; cf. Karppinen 2012; Ziegenspeck et al. 2004; Lähdesmäki and Matilainen 2014; Toivonen et al. 2005; Follo et al. 2017). This means that forest owners in different areas have different extents of linkage to agriculture (typically, this seems to have been greater in, e.g., parts of continental Europe; e.g. Hogl et al. 2005), whereas in forestlands in particular in northermost Europe this might not have been the case, largely also due to the more marginal soils in this area by comparison. The great variation, and also confusion, that arises when trying to depict "forest owners" thus also results from forest ownership having thus far been depicted in a largely nationally based literature, which has most often naturalised the characteristics amongst forest owners in the national context without necessarily comparing them with other cases (Hogl et al. 2005; cf. Ficko et al. 2017). To understand the real variation in forest owners and in their relation to agriculture as well as other uses, it may therefore be relevant to better develop not only contextualised national descriptions, which clarify what are often national assumptions, but also explicit comparisons. It may also be relevant to explicitly contextualise and describe the role of forest ownership within rural areas, to add to what has to date been a largely agriculturally focused rural studies literature. Due to this, literature on forest ownership or forest lands has not necessarily been influenced by preconceptions in rural literature, but at the same time has not been able to strongly influence this literature or provide a broader forest context to rural studies (e.g. Cruickshank 2009; cf. Hogl et al. 2005).

Variations in what characteristics the traditional forest owner is assumed to hold, however, are great across the literature: in many central or southern European cases the focus is often on forestry in combination with agriculture. There are also assumptions regarding forest-owner characteristics inherent even in conceptions of forest owners that describe them as "family forest owners" or "non-industrial forest owners" (cf. Harrison et al. 2002). While factually correct, these descriptions may obscure the fact that some forest owners-particularly in northern as compared with southern Europe-own relatively large forest properties (Matilainen et al. 2019). Thus, the understanding of small-scale forest ownership has often been based in the specific country context. It has also often rested upon a traditionalised understanding of forest owners. This can be seen, for instance, in an assumption that forest owners are regularly male, are themselves active in forestry, and live in rural areas and predominantly on their own property. There are also some assumptions in the literature that female forest owners may behave in other ways than male forest owners do (which has also been described by Follo et al. 2017). Understanding the "new" types of forest owners must thus start by also problematising what we know of the forestowner characteristics we assume, and what the analysable shift in them is, if any.

A second component of understanding this "newness" relates to problematising from where an assumed shift in forest owner characteristics derives. As globalisation-which is particularly seen as influencing urbanisation (shifts in main 
localisation of habitation and potentially occupation) and increasing the internationalisation of economic production-has often been seen here as unstoppable and as implying a unidirectional shift (Giddens 1999), this also must be problematised. While terms such as "counterurbanisation" seem to imply going against what would otherwise be the assumed order (urbanisation), there is-despite it often being assumed - not any single given direction to change (Ward and Brown 2009). In particular, there cannot be assumed to be any single given direction for change at the individual level, and for individual-level forest-owner characteristics. It may be that even in an urbanising environment, specific occupations are instead drawn to "rural" areas, for instance in cases in which these would possess relevant employment characteristics. It may also be that in such cases, larger landowners reside on their forest property whereas smaller-scale forest owners move to a higher degree (Ward and Brown 2009). However, also in this case, is it not a given that urbanisation would result in changing forest-owner behaviour in relation to one's own forest. A forest owner who changes their location of main residence may still retain their attachment to the property (particularly if moving from the area was not a personal choice but rather the result of employment factors) (Lähdesmäki and Matilainen 2014).

Moving place of residence may thus not over the short term-i.e. concerning the individual owner-imply shifts in forest management behaviour or attachment. For instance, it has been seen that what is "far" away will vary with place attachment and identity, national context, transport technologies and available infrastructure, and that the implication of even moving geographically "far" away can thus not be regarded as given (Kaltenborn and Williams 2002; Lähdesmäki and Matilainen 2014). Over the longer term, however, given the fact that much of attachment to property and lifestyle relates to socialisation factors, the behaviour of new owners-in the understanding of the "next generation" of owners-will become less possible to extrapolate from existing findings. It can be hypothesised that future owners who have not been brought up on the property may not hold similar values to those of previous owners. There is also the question of what the variations may be between those who spend summers and holidays at the cabin (i.e. second home, something that is available to, by some counts, half the population in northern Europe) and thereby gain an attachment to the specific locality, and those who may inherit properties but have not experienced these types of attachment to the locality (e.g. Ellingsen and Hidle 2013; Vepsäläinen and Pitkänen 2010). Potential shifts in the identity, relationship, attributes or use preferences the forest owner displays in relation to their property, or more broadly in relation to a conception of nature or place, are thereby not easily conceived in unitary categories, but are rather part of complexes encompassing not only location but also valuation related to numerous factors-many subjective-related to place. These types of conceptions of multiple attachments are noted in studies ranging from psychology (Elster 1987) to geography (Tuan 1977; Massey 1994). Acknowledging that urban or new forest owners still keep some bonds and may behave partly like traditional/rural forest owners is thus well in line with understandings that highlight the constructed nature of attachment-that any person's bond to area cannot be understood merely through simplified parameters such as geographical distance or, for instance, "forest owner type" (e.g. Hogl et al. 2005; Hidle et al. 2006). 
Understanding forest ownership in this way, as a part of studies that are relevant to not only rural areas but also to an understanding of land use and habitation at large, can thus support a more diverse and correct conception of "rural" areas. In addition, reviewing numerous land uses - and not only often assumed ones such as agriculturecan also provide a better understanding of the actual potentials for economic growth. That forest owners will necessarily move physically, for instance for work, cannot be assumed, as "rural" areas are regularly multifaceted. For instance, reviewing land use within a more integrated context such as the northern European one can illustrate that the attractivity of "rural" areas may be more about where clusters of employment possibilities, including companies, are placed. If companies are in less integrated contexts situated in larger urban areas with only applications in rural land use cases, it may seem likely that the more secure jobs are at the headquarters. On the other hand, if these companies are placed in more rural settings, it may well be that these constitute the secure and attractive employment possibilities for the sector: in this way, it may not be the characteristics of the countryside but rather the characteristics of the assumptions regarding the countryside that create its attractivity (cf. Hidle et al. 2006). These issues of attractivity and the ability to retain employment or business possibilities related to forest owners and potential clusters of factors relevant to them (to a potentially greater extent than the population at large) may also impact the extent to which forest owners are potentially able to retain a relation to land.

To discuss these conceptions, this paper draws upon research, predominantly published papers, which are referred to for further detail. Many of the papers are drawn from the PLURAL project, which focused on the new forest owner as a phenomenon, compared areas in northern and southern Sweden and also established comparisons in relation to international literature and European cases. Additional literature has also been included that specifically speaks to this phenomenon. The paper thus highlights the Swedish case as a relevant example of a complex forestowner situation and a complex interlinkage between rural and urban areas, to provide a perspective on how forest is conceived of, what this type of understanding can add to understandings of the rural, and how it differs from assumptions regarding forest as related to assumptions regarding "wilderness".

The Results section is structured to speak to the issues highlighted in the theoretical background in relation to an understanding of shifts in the situation for forest owners in Sweden that are relevant to a complex understanding of rural areas, including forest. The sections target, respectively, the forest owner as a multiple and complex phenomenon; the role of the forest owner in change; the different types of distance that may impact the relationship between forest owner and land; and the potential of rural forest areas as potential growth areas.

\section{Results}

\section{The Multiple and Complex Nature of the Forest Owner}

In Sweden, about half of all forest-which constitutes 23 million ha of productive forest-is owned by small-scale/private non-industrial forest owners. The average 
size of a property is about 50 ha (with great variation between larger properties in northern Sweden and smaller ones in southern Sweden) - a relatively large property size, particularly in comparison with southern European cases. The variation amongst forest owners is thus substantial (Nordlund and Westin 2010; cf. Ingemarson et al. 2006). The number of forest owners in Sweden is about 340,000 - about $3.7 \%$ of the population - of whom 39\% are female. Most of the forest land is situated in municipalities with more limited population numbers: half of private-owned forest land is situated in municipalities that together have less than $10 \%$ of the national population. Despite the assumption regarding urbanisation as a trend, forest owners today still more often live in these municipalities than people on average do: $42 \%$ of private-owned properties have the owner listed as living on the property, and some $68 \%$ have the owner living less than $10 \mathrm{~km}$ away from the property. On the other hand, female forest owners on average live much further away from their forest than male forest owners do (Lidestav et al. 2015a, b, 2017; Haugen et al. 2016).

In addition, forest owners can of course not be described with entirely "new" or baseline characteristics but rather vary in their combination of different attributes, often down to the individual level and life situation (Westin et al. 2017). While the image of the male forest owner living at location on their property still to some extent holds true, the number of female and also urban owners has increased, particularly over the last 20 years. Nevertheless, this does not seem to have impacted forestry production (which is maintained or higher over time) (cf. Lidestav and Berg Lejon 2013). Also, no clear way can be seen in which these specific characteristics necessarily influence forest management patterns: for instance, women are not necessarily more inclined towards environmental protection in a way that is visible in forest management. Instead, the dividing line in determining what type of management is undertaken seems to be the size of the forest property: owners with larger properties, whether male or female, seem to favour a forest management focused on economic factors (Eggers 2017; Eggers et al. 2014). This may thereby be related to the larger management costs but also the economic gains, and thus the role in the personal economy, that a larger property implies. The forest owner is also older than the population on average. This indicates that larger shifts may occur over time as new generations, with as yet unclear residence and behaviour patterns, come into ownership (Lidestav et al. 2017; Haugen et al. 2016).

In addition, the interlinkage between rural and urban areas is also supported by the fact that in Sweden, as well as Norway and Finland, most of the national population also has access to a second home. Forest owners regularly have a dwelling on their premises, and for many the issue of being a forest owner is multifaceted: some may not even see the forest per se as the resource but rather value various aspects, from the social context or location to family connection, amenity values such as view, berry/mushroom picking, hunting and fishing, or other pursuits (Nordlund et al. 2017; cf. Mattsson and Chuanzhong 1993). Forestry, while often emphasised in literature on forest owners, is thus not necessarily the focus of the individual owner. Instead, it can be seen that forest owners vary over factors such as the roles attributed to family forestry, tradition, and national context (Westin et al. 2017). These types of factors are also underlined more generally in literature. Many people, 
as noted, are only a generation or so away from the farm (Ågren 2001; Sommestad 1998). These legacies can also be seen in present-day institutions that play a part in making such practices possible, such as, notably, the common rights to berry and mushroom picking even on private land, and the relatively large involvement in hunting and fishing as well as "outdoor" activities. This is to the extent that authors have noted that English-language terms such as "outdoor recreation" are not accurate for describing the extent to which these activities are more integrated and naturalised in a Swedish- than an English-language context (Beery 2011).

The Swedish case thereby focuses on a historically very sparse population spread over a large area, and with, in some comparisons, relatively large properties which enable a greater economic outcome and potentially also continued residence in local areas (cf. Westin and Holm 2018). The case can thus not be regarded as "typical" of European forest ownership_-indeed, it has been questioned whether there is anything such as a "typical" forest owner (cf. Ingemarson et al. 2006)—but must instead be seen as an illustration of a very specific and highly historically formed type of forest owner, with great internal complexity and variation.

\section{The Forest Owner in Change: Added Complexity}

How large, then, is the shift in whom the forest owner is, i.e. the characteristics of the forest owner? We have already noted that changes have occurred, entailing a higher proportion of female and urban owners, albeit with a relatively low level of change over time. A significant shift has occurred in education level and employment among forest owners - whereby the education level has developed to be more be on par with the general population, and employment outside forestry is the main income source (Westin et al. 2017). Shifts have also been seen in changing lifestyles of forest owners, with a decreasing fraction of them physically taking on a role in forestry on their own land-something that was previously more common. Thus, many forest owners today purchase forest management services. Owning and managing forest without in essence possessing an embedded knowledge of forestry is made possible by the well-developed institutional framework of forest owners' organisations in Sweden, as well as by the existence of a forest industry with wellestablished forestry services. In the Swedish case, as well as northern European cases more broadly, the forest industry and forest owners' associations also have much larger roles than is the case in many southern European countries, which may influence forest-owner behaviour as well as what comes to be seen as the assumed uses of forest (cf. Lönnstedt 2014; Kronholm 2015). These organisations have been necessitated by the need to ascertain wood supply to industry from the half of all productive forest land owned by small-scale forest owners, and have resulted in the regular purchase of forest services (Keskitalo et al. 2017).

All these changes lead to a growing diversity in forest-owner types (not only female or male, urban or rural resident, etc.) and thus imply a need for revisions to policy instruments and forest management approaches, such as forest owners' associations, advisory and innovation systems, and types of support and management services offered to owners (cf. Weiss et al. 2017). At present, forest owners' 
associations are adjusting to the situation of an increasing fraction of forest owners without a background in forestry, and are establishing forest owners' meetings in urban areas, outreach to urban owners, and the like (cf. Keskitalo et al. 2017). However, there are also concerns that the large outreach and capacity of forestry organisations may in essence mean that forest owners without a forestry background are not able to assess management suggestions by organisations, despite themselves being formally responsible for the management. For instance, owner preferencesfor instance, to increase environmental protection-may not come through in a service buyer process that is largely focused on forestry production, meaning that variations in lifestyle and forest management preferences are not necessarily reflected in an equal variation in management strategies. So far, in addition, changing forestowner characteristics have thus also not resulted in any decrease in forestry production (Lidestav et al. 2017; Haugen et al. 2016). The changing forest owner, thereby, does not seem to per se result in changes in forest management that are visible in the forest, but perhaps thus far instead in outreach and communication activities in forestry based in maintaining existing conditions (cf. Andersson and Keskitalo 2018).

\section{When Does a Forest Owner Live "Far" From Their Own Forest-Does Geographical Migration Result in Changing Relations to Land and Changing Forest Management?}

The question of whether a higher proportion of owners who live off their property, and particularly in urban locations, will result in a changing conception of forest has been a key issue in the debate around "new" (non-traditional) forest owners. As we have seen above, the urban forest owner is still a minority, and forestry production has so far not decreased. Instead, the present research programme has been able to show that forest owners who live in the municipality where their property is situated leave the municipality to a lesser extent than do non-forest owners (for those who have owned their forest holding at least 5 years, about a third as often as other inhabitants of the same age in the municipality). It should be pointed out, though, that as the share of forest owners is low, they only contribute to a mere $2 \%$ of all moves. Private forest ownership can nonetheless be seen to have a positive effect on population development in sparsely populated municipalities. The programme authors conclude that this means that, rather than as traditional measures in rural policy attempting to artificially copy urban services, private forestry is one of few institutions that disregard urbanisation. For many new and old forest owners, their localisation is likely based on closeness to the property of central import, not on whether one or another urban service is available close by Westin and Holm (2018).

However, studies highlight that geographical distance to the forest property is not necessarily a crucial factor influencing attachment, attitude to, and activity in forest management (cf. Gustafson 2006). These elements are also influenced by various sociodemographic characteristics, technologies and infrastructure for travel and management, as well as mental or psychological distance, for instance not having a clear relation to it. This means that even a forest property that is far away can be 
mentally close to and central to its owner (Westin et al. 2017; Bergsten and Keskitalo 2018).

A large interview study selecting forest owners living at different distances from their properties, in different types of municipalities including large urbanities, and with different sociodemographic characteristics, illustrated particularly these factors (Bergsten and Keskitalo 2018). The study illustrated that forest owners' sense of the forest property was constructed by the owner not so much in relation to the geographical distance as in relation to their historically and socially grounded emotional bonds with their forest properties. Examples exist of people living an hour by plane from their property, who nevertheless view the property as central to them, as well as of people who live closer but are less focused on the forest property. The property characteristics that were valued also varied greatly between the different interviewed forest owners, across the full spectrum from social context or family/ inheritance or legacy value to location, amenity values such as view, and use values such as berry/mushroom picking, hunting and fishing, to forestry economic value (Bergsten and Keskitalo 2018). Westin and Holm similarly suggest that there may thus be a "combination effect" of "the importance of a broader set of resource-oriented local amenities for migration and local development" (Westin and Holm 2018: 18, cf. Nordlund et al. 2017). In Bergsten and Keskitalo's case (2018), this combination effect could also be seen for local development and consideration even in light of migration-whereby even those who moved relatively far could conceive of the property as central to them. As a result, the dynamics seen as being related to the property may thereby, in the meaning they are given by the forest owner, serve to retain perspectives relevant to a relation to land.

\section{Rural Forest Areas as Potential Growth Areas}

Finally, the programme also reviewed factors surrounding the influence of forest companies. This assessment was made in the context of the discussion of urban centrality and whether urban areas can be seen as more competitive, posing the question of whether forest can be seen to play a role in relation to nuancing this assessment of competitiveness and centrality, and in fact contributing to a discussion on whether forest ownership may in fact also support retaining a direct forestry economic relation to land.

Haugen and Lindgren (2013: 122) put forward a hypothesis that "a firm whose owner also possesses forest holdings is more viable thanks to the different resources (in the form of capital from logging or mortgaging, or non-pecuniary other values) the forest holdings may provide, and which possibly contribute to the firm's economic stability and resilience to economic fluctuations". The studies illustrated that micro company owners (with less than ten employees) who also own forest show better results, potentially as forest ownership may constitute a buffer enabling the potential for longer-term economic investment. In another study by Borggren et al. (2016), the survival of high-impact firms (i.e. fast-growing firms, sometimes denoted as 'gazelles') was analysed by means of register data, showing that the success of high-impact firms is not entirely an urban or a metropolitan phenomenon. 
In a book chapter entitled "Is there an end to the concentration of businesses and people?" Lindgren et al. (2017) investigated the chances rural areas have to compete for jobs and income with city regions. A closer study of a handful of successful forest-related firms located in rural areas provided a number of clues to their success. Many of these firms had experienced a process of stepwise innovations together with users. If there had not been demanding local users, the products would never have developed into the high-end quality products needed for successful competition on global markets. Another trait of these firms was that they all had historical linkages to a dominant local trade and industry, which in most cases entailed local forestry activities. The successful firms were commonly spinoffs from other existing companies nearby. Many had their operations located in close proximity to other related companies. The study thus concluded that firms in rural areas may be as competitive and successful as their urban peers, but that this success requires access to assets related to natural resources, human capital and networks: rural cases that include trust between people, potentially decreased competition amongst companies and greater loyalty of employees, tacit knowledge through interaction in the sector, and avoidance of agglomeration negatives such as criminality can thereby provide rural areas with a relevant co-localisation advantage. In comparison, studies on nature-based tourism in Sweden have illustrated both the great role of nature amenities (even when not self-owned) and public infrastructure in tourism development (Margaryan 2016; Margaryan and Wall-Reinius 2017).

As a result, a suggestion is that advantages of co-localisation of related companies or business are well able to exist outside urban areas (cf. Brouder et al. 2015). For forestry, a smallness of regional economy can be compensated for by a concentration of similar and related economic activities: there is no deterministic principle to favour urban regions. Instead, these studies seemed to support the conclusionalso partly seen in relation to other studies, discussed above-that forest ownership and a relation to forest could instead support and add to a rural linkage, in multiple aspects.

\section{Discussion and Conclusion}

The studies described in this article can be seen to illustrate, in the words of the conclusion to the programme's book project, that "forest in rural studies does not have only one meaning" (Keskitalo 2017: 305). However, there are shifts in identity, relation, and attributes of forest owners, varying enough that it is not possible to speak of only single type of "new" owner compared with any single type of "traditional" owner. Instead, forest owners are highly varying, in both their relation to their property and their conception of distance to it. The shifts in forest-owner characteristics, buffered by shifts in outreach and communication amongst forest owners' associations and other forestry organisations, have so far also not influenced forestry to the extent that any potentially diminishing interest in forestry can be seen to influence forest management.

In addition, forest ownership can be seen to support both a relation of perceived nearness and importance of the property and in some cases a relation to the wider 
location, in light of the social implications of or implied by property ownership. This may support a continued relation to land beyond what could otherwise be expected by persons who have moved geographically far from their property. Studies thereby illustrate that geographic remoteness may to some extent be compensated for by other relations to forestry.

In addition, it can also be seen that forest ownership may economically support forest owners-even those active in other sectors. The studies summarised above have also illustrated that the type of forest-related activities that may be of more relevance to forest owners than to the population in general may not necessarily be supported by migration. Instead, the studies show that it is quite possible to maintain employment clusters of the type regularly discussed for urban areas in rural areas as well, for instance for forest-related professions. As a result, broader assumptions regarding attractiveness and possibilities for specialised employment in the countryside (cf. Florida 2004) also need to be broken down with respect to the specific sectors and types of jobs targeted: it is possible that forest-related professions may find clusters of high specialisation and also attractivity in specialised regions.

These conclusions go some way towards also answering the more hypothetical question in the introduction: might any shifts in forest-owner characteristics influence what have been seen as more integrated northern European relations to nature, in the case of these forest owners?

In general, the studies summarised here illustrate that a naturalised and practised linkage to land is a concurrent feature amongst forest owners. Many live on or close to their holdings, and even many living far away express that the value they gain from their holdings relate to a very broad scope of characteristics that can most closely be connected to a relation to land: they describe family and social connections, including an historical or legacy relevance of keeping the forest land in the family, as well as the importance of multiple use but also practice values such as mushroom and berry picking, as well as forestry. Forest is thus inherently a broader context than the physical place; it is also the implied and subjective connection related to family history, and sometimes motivates the continued ownership of the property (cf. Tuan 1977; Massey 1994). Overall, the studies illustrate, forest holdings are not associated with "wilderness" but rather with great and wide-ranging social attachments and activities. Understanding the role of forest in the rural landscape can thereby contribute to a better and diversified understanding of its multiple uses-even by users and interests that are not present but are nonetheless invested in the landscape and its development (cf. Živojinović et al. 2015).

Acknowledgements Open access funding provided by Umea University/SLU. I am grateful to Gun Lidestav and Kerstin Westin for checking and correcting the description and interpretation of their work in the manuscript, and for suggesting additional references. Funding was provided by Svenska Forskningsrådet Formas (Planning for rural-urban dynamics: living and acting at several places PLURAL research programme).

Open Access This article is distributed under the terms of the Creative Commons Attribution 4.0 International License (http://creativecommons.org/licenses/by/4.0/), which permits unrestricted use, distribution, and reproduction in any medium, provided you give appropriate credit to the original author(s) and the source, provide a link to the Creative Commons license, and indicate if changes were made. 


\section{References}

Ågren M (2001) Asserting one's rights: Swedish property law in the transition from community law to state law. Law Hist Rev 19(2):241-282

Andersson E, Keskitalo ECH (2018) Adaptation to climate change? Why business-as-usual remains the logical choice in Swedish forestry. Glob Environ Change 48(1):76-85

Beery T (2011) Nordic in nature: friluftsliv and environmental connectedness. Dissertations, University of Minnesota, ProQuest/UMI (umn11804)

Bergsten S, Keskitalo ECH (2018) Feeling at home from a distance? How geographical distance and non-residency shape sense of place among private forest owners. Soc Nat Resour. https://doi. org/10.1080/08941920.2018.1533607

Borggren J, Eriksson RH, Lindgren U (2016) Knowledge flows in high-impact firms: how does relatedness influence survival, acquisition and exit? J Econ Geogr 16(3):637-665

Brouder P, Karlsson S, Lundmark L (2015) Hyper-production: a new metric of multifunctionality. Eur Countrys 3:134-143

Cronon W (1996) The trouble with wilderness: or, getting back to the wrong nature. Environ Hist 1(1):7-28

Cruickshank JA (2009) A play for rurality-modernization versus local autonomy. J Rural Stud 25:98-107

Eggers J (2017) Development and evaluation of forest management scenarios. PhD thesis, Swedish University of Agricultural Sciences, Uppsala

Eggers J, Lämås T, Lind T, Öhman K (2014) Factors influencing the choice of management strategy among small-scale private forest owners in Sweden. Forests 5:1695-1716

Ellingsen WG, Hidle K (2013) Performing home in mobility: second homes in Norway. Tour Geogr 15(2):250-267

Elster J (ed) (1987) The multiple self. Cambridge University Press, Cambridge

Ficko A, Lidestav G, Ní Dhubháinc A, Karppinen H, Zivojinovic I, Westin K (2017) European private forest owner typologies: a review of methods and use. For Policy Econ. https://doi.org/10.1016/j. forpol.2017.09.010

Florida R (2004) The rise of the creative class; and how it's transforming work, leisure, community and everyday life. Basic Books, New York

Follo G, Lidestav G, Ludvig A, Vilkriste L, Hujala T, Karppinen H, Didolot F (2017) Gender in European forest ownership and management: reflections on women as "New forest owners". Scand J For Res 32(2):174-184

Giddens A (1999) Runaway world: how globalisation is reshaping our lives. Profile, London

Gustafson P (2006) Place attachment and mobility. In: McIntyre N, Williams D, McHugh K (eds) Multiple dwelling and tourism: negotiating place, home and identity. CAB International, Wallingford, pp 17-31

Harrison S, Herbohn J, Niskanen A (2002) Non-industrial, smallholder, small-scale and family forestry: what's in a name? Small Scale For Econ Manag Policy 1(1):1-11

Haugen K, Lindgren U (2013) On the importance of forest assets for micro-firm performance. Fennia 191(2):122-142

Haugen K, Karlsson S, Westin K (2016) New forest owners: change and continuity in the characteristics of Swedish non-industrial private forest owners (NIPF owners) 1990-2010. Small Scale For 15(4):533-550

Hidle K, Cruickshank J, Nesje LM (2006) Market, commodity, resource, and strength: logics of Norwegian rurality. Norsk Geografisk Tidsskrift [Nor J Geogr] 60(3):189-198

Hogl K, Pregernig M, Weiss G (2005) What is new about new forest owners? A typology of private forest ownership in Austria. Small Scale For Econ Manag Policy 4(3):325-342

Howley P (2013) Examining farm forest owners' forest management in Ireland: the role of economic, lifestyle and multifunctional ownership objectives. J Environ Manag 123:105-112

Hujala T, Kurttila M, Karppinen H (2013) Customer segments among family forest owners: combining ownership objectives and decision-making styles. Small Scale For 12(3):335-351

Ingemarson F, Lindhagen A, Eriksson K (2006) A typology of small-scale private forest owners in Sweden. Scand J For Res 21(3):249-259

Johansson E (ed) (2002) Periferins landskap—historiska spår och nutida blickfält i svensk glesbygd. Nordic Academic Press, Lund 
Kaltenborn BP, Williams DR (2002) The meaning of place: attachments to Femundsmarka National Park, Norway, among tourists and locals. Norsk Geografisk Tidsskrift [Nor J Geogr] 56(3):189-198

Karppinen H (2012) New forest owners and owners-to-be: apples and oranges? Small Scale For 11(1):15-26

Keskitalo ECH (2017, ed) Globalisation and change in forest ownership and forest use: natural resource management in transition. Palgrave Macmillan, Basingstoke

Keskitalo ECH (2017) Conclusion. In: Keskitalo ECH (ed) Globalisation and change in forest ownership and forest use: natural resource management in transition. Palgrave Macmillan, Basingstoke, pp 303-314

Keskitalo ECH, Lidestav G, Karppinen H, Zivojinovic I (2017) Is there a new European forest owner? The institutional context. In: Keskitalo ECH (ed) Globalisation and change in forest ownership and forest use: natural resource management in transition. Palgrave Macmillan, Basingstoke, pp 17-56

Kronholm T (2015) Forest owner associations in a changing society. Doctoral thesis, Swedish University of Agricultural Sciences, Umeå, Acta Universitatis Agriculturae Sueciae, 2015:102

Lähdesmäki M, Matilainen A (2014) Born to be a forest owner? An empirical study of the aspects of psychological ownership in the context of inherited forests in Finland. Scand J For Res 29(2):101-110

Lidestav G, Berg Lejon S (2013) Harvesting and silvicultural activities in Swedish family forestrybehavior changes from a gender perspective. Scand J For Res 28(2):136-142

Lidestav G, Lind T, Appelstrand M, Keskitalo C, Westin K, Wilhelmsson E (2015a) Forest land ownership change in Sweden. COST action FACESMAP country reports, European Forest Institute Central-East and South-East European Regional Office, Vienna, $50 \mathrm{pp}$

Lidestav G, Ni Dhubhain A, Karppinen H (2015b) Forest owner types in Europe: diversity and trends. In: Živojinović I, Lidestav G, Feliciano D, Hujala T, Lawrence A, Weiss G (eds) Concepts, methods and findings in forest ownership research in Europe. Mid-term proceedings of the COST action FP1201 forest land ownership changes in Europe: significance for management and policy FACESMAP, EFICEEC-EFISEE Research Report, University of Natural Resources and Life Sciences, Vienna (BOKU), Vienna, Austria, $120 \mathrm{pp}$

Lidestav G, Thellbro C, Sandström P, Lind T, Holm E, Olsson O, Westin K, Karppinen H, Ficko A (2017) Interactions between forest owners and their forests. In: Keskitalo ECH (ed) Globalisation and change in forest ownership and forest use: natural resource management in transition. Palgrave Macmillan, London, pp 97-137

Lindgren U, Borggren J, Karlsson S, Eriksson RH, Timmermans B (2017) Is there an end to the concentration of businesses and people? In: Keskitalo ECH (ed) Globalisation and change in forest ownership and forest use: natural resource management in transition. Palgrave Macmillan, Basingstoke, pp 139-182

Lönnstedt L (2014) Swedish forest owners' associations: establishment and development after the 1970s. Small Scale For 13(2):219-235

Margaryan L (2016) Nature as a commercial setting: the case of nature-based tourism providers in Sweden. Curr Issues Tour 21:1-19

Margaryan L, Wall-Reinius S (2017) Commercializing the unpredictable: perspectives from wildlife watching tourism entrepreneurs in Sweden. Hum Dimens Wildl 22(5):406-421

Massey D (1994) Space, place and gender. Polity Press, Cambridge

Matilainen A, Koch M, Zivojinovic I, Lähdesmäki M, Lidestav G, Karppinen H et al (2019) Perceptions of ownership among new forest owners-a qualitative study in European context. For Policy Econ 99:43-51

Mattsson L, Chuanzhong L (1993) The non-timber value of northern Swedish forests. Scand J For Res 8(1-4):426-434

Morrison TH, Lane MB, Hibbard M (2015) Planning, governance and rural futures in Australia and the USA: revisiting the case for rural regional planning. J Environ Plan Manag 58(9):1601-1616

Murdoch J, Pratt AC (1993) Rural studies: modernism, post-modernism and the 'post-rural'. J Rural Stud 9(4):411-427

Nash R (2014 [1967]) Wilderness and the American mind. Yale University Press, Yale

Nordlund A, Westin K (2010) Forest values and forest management attitudes among private forest owners in Sweden. Forests 2(1):30-50

Nordlund A, Schenk T, Westin K (2017) Forest beliefs in an urbanizing world: views on and usage of forest areas among persons with and without a migration biography in Germany and Sweden. Soc Nat Resour 30(2):160-176 
Scott M (2008) Managing rural change and competing rationalities: insights from conflicting rural storylines and local policy making in Ireland. Plan Theory Pract 9(1):9-32

Shubin S (2006) The changing nature of rurality and rural studies in Russia. J Rural Stud 22(4):422-440

Sommestad L (1998) Human reproduction and the rise of welfare states: an economic-demographic approach to welfare state formation in the United States and Sweden. Scand Econ Hist Rev 46(2):97-116

Svensson E (2016) Iscensättning av utmarksbruk-en innovationshistoria. I. In: Gustin I, Hansson M, Roslund M, Wienberg J (eds) Mellan slott och slagg Vänbok till Anders Ödman. Institutionen för Arkeologi Och Antikens Historia, Lunds Universitet, Lund, pp 267-272

Swaffield S, Fairweather J (1998) In search of arcadia: the persistence of the rural idyll in New Zealand rural subdivisions. J Environ Plan Manag 41(1):111-128

Toivonen R, Järvinen E, Lindroos K, Rämö AK, Ripatti P (2005) The challenge of information service development for private forest owners: the Estonia and Finland cases. Small Scale For Econ Manag Policy 4(4):451-469

Tuan Y-F (1977) Space and place: the perspective of experience. University of Minnesota Press, Minneapolis

Vepsäläinen M, Pitkänen K (2010) Second home countryside. Representations of the rural in Finnish popular discourses. J Rural Stud 26:194-204

Ward N, Brown DL (2009) Placing the rural in regional development. Reg Stud 43(10):1237-1244

Weiss G, Lawrence A, Lidestav G, Feliciano D, Hujala T (2017) Changing forest ownership in Europe? Main results and policy implications, COST action FP1201 FACESMAP policy paper, BOKU, Vienna, $25 \mathrm{pp}$

Westin K, Holm E (2018) Do trees make people more rooted? Private forest owners' migration behaviour. For Policy Econ 94:11-20

Westin K, Eriksson L, Lidestav G, Karppinen H, Haugen K, Nordlund A (2017) Individual forest owners in context. In: Keskitalo ECH (ed) Globalisation and change in forest ownership and forest use: natural resource management in transition. Palgrave Macmillan, London

Ziegenspeck S, Härdter U, Schraml U (2004) Lifestyles of private forest owners as an indication of social change. For Policy Econ 6(5):447-458

Živojinović I, Weiss G, Lidestav G, Feliciano D, Hujala T, Dobšinská Z, Lawrence A, Nybakk E, Quiroga S, Schraml U (2015) Forest land ownership change in Europe. COST action FP1201 FACESMAP country reports, joint volume. EFICEEC-EFISEE research report

Publisher's Note Springer Nature remains neutral with regard to jurisdictional claims in published maps and institutional affiliations. 